\title{
QUINOA (Chenopodium quinoa Willd.) - A POTENTIAL NEW CROP IN BANGLADESH: AGRONOMIC PERFORMANCE WITH SOWING DATE
}

\author{
P.K. Biswas ${ }^{1}$ and Z.A. Tanni ${ }^{2}$ \\ ${ }^{1}$ Department of Agronomy, Sher-e-Bangla Agricultural University, Dhaka \\ 2IST, Sher-e-Bangla Agricultural University, Dhaka \\ Corresponding E-mail: parimalbiswas@hotmail.com
}

(Received: 27 May 2020, Accepted: 24 August, 2020)

Keywords: Bangladesh, quinoa, optimum sowing date, yield, nutrition

\begin{abstract}
The experiment was conducted at Sher-e-Bangla Agricultural University, Dhaka with the financial support of SAURES (Sher-e-Bangla Agricultural University Research System) to study the possibility of growing quinoa in Bangladesh with different sowing dates having two cultivars. The experiment comprised of two factors; Factor A: Cultivar (2) viz., Titicaca $\left(\mathrm{C}_{1}\right)$ and Vikinga $\left(\mathrm{C}_{2}\right)$ and Factor B: Sowing date (5) viz. November -10 $\left(\mathrm{S}_{1}\right)$, December -10 $\left(\mathrm{S}_{2}\right)$, January -10 $\left(\mathrm{S}_{3}\right)$, February -10 $\left(\mathrm{S}_{4}\right)$ and March -10( $\left.\mathrm{S}_{5}\right)$. The experiment was laid out in split-plot design with three replications. Results revealed that different growth parameters, yield attributes and yield were significantly varied with different sowing dates. At harvest, the tallest plant height $(63.75 \mathrm{~cm})$, highest seed yield $\left(0.77 \mathrm{tha}^{-1}\right)$ and straw yield $\left(0.89 \mathrm{t} \mathrm{ha}^{-1}\right)$ was found from Titicaca but the higher number of branches plant ${ }^{-1}$ (17.71) from Vikinga. The tallest plant height $(62.54 \mathrm{~cm})$, highest branch number plant ${ }^{-1}(22.82)$, longest inflorescence $(29.62 \mathrm{~cm})$, highest 1000-seed weight $(2.56 \mathrm{~g})$, seed yield (1.09 $\left.\mathrm{t} \mathrm{ha}^{-1}\right)$, straw yield $\left(1.25 \mathrm{t} \mathrm{ha}^{-1}\right)$ and harvest index $(46.58 \%)$ was exhibited by November -10 sowing. The interaction effect of Titicaca sown in November -10 $\left(\mathrm{C}_{1} \mathrm{~S}_{1}\right)$ resulted the highest plant height at harvest $(72.83 \mathrm{~cm})$, branches plant ${ }^{-1}$ (25.20), 1000-seed weight (2.58 g), seed yield (1.16 t ha-1) and straw yield (1.33 t $\left.\mathrm{ha}^{-1}\right)$ but the highest inflorescence length $(31.46 \mathrm{~cm})$ and harvest index $(47.02 \%)$ from $\mathrm{C}_{2} \mathrm{~S}_{2}$ (Vikinga sown in December - 10). From the above results it can be concluded that quinoa - as a new crop is suitable to cultivate in Rabi season of Bangladesh with a complete agronomic management package.
\end{abstract}

\section{Introduction}

Quinoa (Chenopodium quinoa willd.) is a yearly herbaceous plant belongs to Amaranthaceae family that originated in the appeasing slopes of the Andes in South America. It was cultivated and worn by the Inca (ruling class) people since 5,000 B.C. It is obsessive in broad diversity of forms i.e., grains, flakes, pasta, bread, biscuits, beverages, meals etc. Quinoa is revealed as a strength rations by North Americans and Europeans in the 1970"s and its reputation is dramatically increased in recent years because it is gluten-free (helpful for diabetic patients) and high in protein. In 2018, world production of quinoa was 158,920 tonnes, led by Peru and Bolivia with 99\% of the total combined (FAOSTAT, 2020).

Quinoa is a quick-rising plant, grows up to $2 \mathrm{~m}$ tall with exchange, thickly ragged, triangular to ovate vegetation. Every inflorescence produced hundreds of little achiness, approximately $2 \mathrm{~mm}$ in width. Quinoa is an achene (a seed-similar to fruit with a firm fur) with diversified colours 
ranging from white or pale yellow to orange, red, brown and black. An ideal average temperature for quinoa would be around $15-20^{\circ} \mathrm{C}$, but some specific landraces can also withstand extreme temperatures from $8^{\circ} \mathrm{C}$ to $+38^{\circ} \mathrm{C}$ (Bazile et al., 2015).

Quinoa grain is the only vegetable food that provides all amino acids fundamental to the life of humans in most favorable quantities and is comparable with milk. The crop is rich in protein (7.47 to $22.08 \%)$ with higher concentration of lycine, isoleucine, methionine, histidine, cystine and glycine. The ash substance is 3.4 per cent containing high amount of $\mathrm{Ca}, \mathrm{Fe}, \mathrm{Zn}, \mathrm{Cu}$ and $\mathrm{Mn}$. The oil content is 1.8 to 9.5 per cent and loaded in necessary fatty acids like linoleate and linolenate. In adding up, quinoa seed is wealthy in thiamine $(0.4 \mathrm{mg})$, folic acid $(78.1 \mathrm{mg})$, vitamin C (16.4 mg), riboflavin $(0.39 \mathrm{mg})$ and carotene $(0.39 \mathrm{mg})$ in $100 \mathrm{~g}$ seed, respectively. The calorific assessment is $350 \mathrm{cal}$ per $100 \mathrm{~g}$ grains and is bigger than that of additional cereal and legume foods and its glycemic index is 53 which is much lower than white rice. The digest ability of quinoa protein is more than 80 per cent. Quinoa also have usual defiant Oxidants like -tocopheral $(5.3 \mathrm{mg}), \gamma$-tocopheral $(2.6 \mathrm{mg}$ ) in $100 \mathrm{~g}$ seed and phytoestrogens that avoid regular diseases such as osteoporosis, breast cancer, heart diseases and additional feminine troubles caused by require of estrogen during the menopause. FAO declared 2013 as International year of Quinoa (Bhargava et al., 2006).

The importance of quinoa is getting momentum around the world due to its ability to withstand in extreme conditions (Bazile et al., 2015). The high genetic diversity of the crop provides its opportunities for leveraging its hardiness and further wide adaptation (Louafi et al., 2013). Today, drought and soil salinization are major limiting factors in cultivation, a fact that is generating significant pressure on arable land availability. Considering these major challenges, the crop is presently cultivated, or is under experimentation, in more than 95 countries and its cultivation continue to expand rapidly worldwide (Bazile, 2014; Bazile et al., 2016). The cultivation of quinoa spreading throughout the world as far as Tibet, Morocco, France, India, China, the United Kingdom, Sweden, Denmark, Netherlands, Canada, USA, Australia, Thailand, Kenya and Italy, among others (Bhargava et al., 2006; Pulvento et al., 2010; Bazile et al., 2015).

A balanced diet, adequate in all necessary nutrients; energy, protein, vitamins and minerals, can satisfy both perceptible and hidden hunger (Jahan and Hossain, 1998). Though rice as a cereal is the main food of Bangladesh, it is not well balanced and as a result children and women suffer from high levels of malnutrition and micronutrient deficiencies such as low birth weight, undernutrition, vitamin A deficiency, iodine-deficiency disorders and iron-deficiency anaemia. At the same time, new health problems related to over-nutrition such as obesity are emerging (World Bank, 2005).

Optimum planting time is the first step and measured as a base that leads to growth of appropriate manufacture technology particularly for a new-fangled crop in a particular area (Sajjad et al., 2014). There is no research has yet been conducted to introduce quinoa in Bangladesh. Hence it is high time to introduce the crop like quinoa in Bangladesh to supplement for the malnutrition facing by the country people's. Therefore the experiment was undertaken during Rabi season taking two Danish cultivars and different dates of sowing to identify the optimum sowing date of quinoa for the prevailing climatic condition of Bangladesh.

\section{Materials and Methods}

The experiment was conducted at the Agronomy Farm of Sher-e-Bangla Agricultural University (SAU), Dhaka that located in $23^{\circ} 77^{\prime} \mathrm{N}$ latitude and $90.26^{\circ} \mathrm{E}$ longitudes during November, 2017 to July, 2018. The general soil type of the experimental field was deep red brown terrace 
soil belongs to the Tejgaon series under the Agroecological Zone, Madhupur Tract (AEZ-28). The soil was consuming a texture of silty clay with $\mathrm{pH} 5.6$ and organic matter $0.78 \%$, sand $26 \%$, silt $45 \%$ and clay 29\%. During the experimental period the maximum temperature $\left(39.4^{\circ} \mathrm{C}\right)$, highest relative humidity $(78 \%)$ and highest rainfall $(277 \mathrm{~mm})$ and the minimum temperature $\left(17^{\circ} \mathrm{C}\right)$ and minimum relative humidity $(64 \%)$ was recorded. The experiment comprised of two factors; Factor A: Cultivar (2) - Titicaca $\left(\mathrm{C}_{1}\right)$ and Vikinga $\left(\mathrm{C}_{2}\right)$, Factor B: Sowing dates $(5)$ - November -10 $\left(\mathrm{S}_{1}\right)$, December -10 $\left(\mathrm{S}_{2}\right)$, January -10 $\left(\mathrm{S}_{3}\right)$, February -10 $\left(\mathrm{S}_{4}\right)$ and March -10 $\left(\mathrm{S}_{5}\right)$. Two Danish cultivars e.g., Titicaca and Vikinga was collected from DAE, Bangladesh. Initially the experiment was designed with a sowing date of each month but finally the plants of April and May sowing were damaged and June to October sowing were not possible due to excessive soil moisture.

The land was opened on the 05 November, 2017. Urea, Triple super phosphate (TSP) and Muriate of potash (MoP) @180, 152 and $63 \mathrm{~kg} \mathrm{ha}^{-1}$ were added in the experimental soil as a source of nitrogen $(\mathrm{N})$, phosphorous $(\mathrm{P})$ and potassium $(\mathrm{K})$, respectively. Full dose of TSP and $\mathrm{MoP}$ along with one third urea were applied in final land preparation as basal dose and the rest amount of urea was top dressed at 25 and 40 DAS (Risi and Nicholas, 1991). The experiment was laid out in a split-plot design with three replications where cultivars were assigned in the main plot and sowing dates in sub-plot. The first sowing was done on November -10, 2017 in solid rows in the furrows having a depth of $2-3 \mathrm{~cm}$ and row to row distance was $30 \mathrm{~cm}$. Other seed sowing were done as per treatment. Thinning was done two times; first at 10 DAS and second at 15 DAS to maintain optimum plant population in each plot. Irrigation was given at 15 and 30 DAS for optimizing the vegetative growth for all experimental plots equally and supplementary irrigation was maintained as and when necessary. Proper drainage facilities was also maintained accurately to remove excess water from the experimental plot. The field was weeded twice at 20 and 35 DAS by hand weeding. Five plants from each plot were randomly selected and marked with sample card from which plant height and branches plant ${ }^{-1}$ were recorded at different growth stages. Length of inflorescences plant ${ }^{-1}, 1000$-seed weight, seed and straw yield were recorded at harvest. Harvesting was done when $90 \%$ of the grain became green to yellow (Titicaca) and red (Vikinga) in color. The matured crops were collected by hand picking from each plot. The collected crops were sun dried, threshed and the seeds were separated, cleaned and dried in the sun for 3 to 5 consecutive days for achieving safe moisture of seed. The dried seeds and straw were cleaned and weighed. The collected data were compiled and analyzed statistically using the analysis of variance (ANOVA) technique with the help of CropStat and the mean differences were adjudged by least significant difference (LSD) test at 5\% level of significance (Gomez and Gomez, 1984).

\section{Results and Discussion}

\section{Effect of cultivar}

Plant height at 15 DAS showed non-significant variation for different cultivars but at 30 DAS and harvest significant variation was observed (Table 1). At 30 DAS, the higher plant height $(57.55 \mathrm{~cm})$ was obtained from Titicaca and the lower $(44.37 \mathrm{~cm})$ from Vikinga. Similar trend was also followed at harvest with higher plant height $(63.75 \mathrm{~cm})$ of Titicaca compared to that of Vikinga $(50.62 \mathrm{~cm})$. The plant height of Titicaca at harvest was $20.58 \%$ higher than Vikinga. Such higher plant height of Titicaca might be due to its genetical character. The result was similar with the findings of Fernando et al. (2012) who conducted a research on quinoa cultivars viz. Titicaca and Vikinga and found higher plant height from Titicaca. Branches plant ${ }^{-1}$ at 30 DAS and harvest showed significant variation for cultivars but non-significant at 15 DAS (Table1). The higher number of branches plant ${ }^{-1}$ (16.11 and 17.11) was obtained from Vikinga 
compared to Titicaca (15.05 and 16.59) at 30 DAS and harvest, respectively. Inflorescence length and 1000-seed weight showed non-significant variation for cultivars. Seed yield of quinoa showed significant variation for cultivars. The higher seed yield $\left(0.77 \mathrm{t} \mathrm{ha}^{-1}\right)$ from Titicaca and the lower $\left(0.61 \mathrm{t} \mathrm{ha}^{-1}\right)$ from Vikinga. The Titicaca yield was $26.23 \%$ higher than Vikinga. Similarly higher straw yield $\left(0.89 \mathrm{t} \mathrm{ha}^{-1}\right)$ was obtained from Titicaca and the lower $\left(0.76 \mathrm{t} \mathrm{ha}^{-1}\right)$ from Vikinga. No significant variations for harvest index was observed between the two cultivars (Table 2).

\section{Effect of sowing date}

Plant height at 15, 30 DAS and harvest showed significant variation for different sowing dates (Table1). At 15 DAS, the highest plant height $(44.57 \mathrm{~cm})$ was obtained from February -10 sowing and the lowest $(22.62 \mathrm{~cm})$ from November -10 sowing. At 30 DAS, the highest plant height $(55.63 \mathrm{~cm})$ was obtained from January -10 sowing and the lowest $(38.10 \mathrm{~cm})$ from March -10 sowing. At harvest, the maximum plant height $(62.54 \mathrm{~cm})$ was obtained from November -10 sowing that similar to all other sowings except March -10 sowing that showed the lowest plant height $(42.75 \mathrm{~cm})$. These results were supported with the findings of Troiani et al. (2004) who conducted a research on quinoa time sowing and reported second half of the November to the end of December showed the highest plant height. Number of branches plant ${ }^{-1}$ at 15, 30 DAS and harvest showed significant variation for different sowing dates (Table1). At 15 and 30 DAS, the highest number of branches plant ${ }^{-1}$ (23.60 and 25.83) was obtained from January -10 sowing and the lowest number of branches (5.50 and 10.13) obtained from November -10 sowing, respectively. At harvest, the highest branch number (23.45) was obtained from January -10 sowing that similar to December - 10 and November -10 sowing and the lowest branch number (6.51) from March-10 sowing. The highest inflorescence length plant ${ }^{-1}$ $(29.62 \mathrm{~cm})$ was obtained from November - 10 sowing that similar to December - 10 sowing $(28.33 \mathrm{~cm})$ and the lowest inflorescence length $(13.85 \mathrm{~cm})$ obtained from March -10 sowing. Weight of 1000-seed of quinoa showed significant variation for different sowing dates (Table 2) where the highest 1000 -seed weight $(2.56 \mathrm{~g})$ was obtained from November -10 sowing that similar to December - 10 sowing $(2.47 \mathrm{~g})$ and the lowest 1000 -seed weight $(1.17 \mathrm{~g})$ from March -10 sowing. November sowing produced seed with 118\% higher size compared to that of March sowing. Seed size is an important parameter for quinoa seed germination capacity as Koyro and Eisa (2007) reported that smaller seed size of quinoa showed lower germination capacity.

Table 1. Effect of cultivar and sowing date on plant height and branch number plant ${ }^{-1}$ of quinoa

\begin{tabular}{lcccccc}
\hline Treatments & \multicolumn{3}{c}{ Plant height $(\mathbf{c m})$ at } & \multicolumn{3}{c}{ Branches plant ${ }^{\mathbf{1}}$ (no.) at } \\
\cline { 2 - 7 } & 15 DAS & 30 DAS & Harvest & 15 DAS & 30 DAS & Harvest \\
\hline Effect of cultivar & & & & & & \\
Titicaca & 37.49 & $57.55 \mathrm{a}$ & $63.75 \mathrm{a}$ & 12.21 & $15.05 \mathrm{~b}$ & $16.59 \mathrm{~b}$ \\
Vikinga & 29.36 & $44.37 \mathrm{~b}$ & $50.63 \mathrm{~b}$ & 13.22 & $16.11 \mathrm{a}$ & $17.71 \mathrm{a}$ \\
LSD $(0.05)$ & $\mathrm{NS}$ & 12.936 & 12.728 & NS & 1.026 & 1.073 \\
CV (\%) & 17.30 & 17.41 & 14.16 & 13.42 & 18.32 & 19.23 \\
Effect of sowing date & & & & & & \\
November - 10 & $22.62 \mathrm{~b}$ & $54.57 \mathrm{a}$ & $62.54 \mathrm{a}$ & $5.50 \mathrm{~d}$ & $10.13 \mathrm{c}$ & $22.84 \mathrm{a}$ \\
December - 10 & $29.52 \mathrm{~b}$ & $54.49 \mathrm{a}$ & $62.47 \mathrm{a}$ & $9.20 \mathrm{c}$ & $13.32 \mathrm{bc}$ & $22.80 \mathrm{a}$ \\
January-10 & $44.23 \mathrm{a}$ & $55.63 \mathrm{a}$ & $60.46 \mathrm{a}$ & $23.60 \mathrm{a}$ & $25.83 \mathrm{a}$ & $23.45 \mathrm{a}$ \\
February-10 & $44.57 \mathrm{a}$ & $52.01 \mathrm{a}$ & $57.73 \mathrm{a}$ & $14.65 \mathrm{~b}$ & $16.79 \mathrm{~b}$ & $10.15 \mathrm{~b}$ \\
March - 10 & $26.17 \mathrm{~b}$ & $38.10 \mathrm{~b}$ & $42.75 \mathrm{~b}$ & $10.64 \mathrm{c}$ & $11.82 \mathrm{c}$ & $6.51 \mathrm{c}$ \\
\hline LSD $(0.05)$ & 10.000 & 8.749 & 8.282 & 2.402 & 3.524 & 2.704 \\
CV (\%) & 24.69 & 14.03 & 11.83 & 15.44 & 18.49 & 12.88 \\
\hline
\end{tabular}

Figures in a column with common letter(s) do not differ significantly at $5 \%$ probability level. 
Seed yield of quinoa showed significant variation for different sowing dates and the highest yield (1.09 $\mathrm{t} \mathrm{ha}^{-1}$ ) was obtained from November -10 sowing that followed by December -10 sowing $\left(0.88 \mathrm{t} \mathrm{ha}^{-1}\right)$ and the lowest seed yield $\left(0.26 \mathrm{tha}^{-1}\right)$ from March -10 sowing. The seed yield of quinoa was reduced by 19.27, 32.11, 55.96 and 76.15\% for December, January, February and March sowing, respectively compared to that of November sowing. Higher seed yield of quinoa at 15 October sowing was also reported by Ramesh et al. (2017). The highest straw yield (1.25 t $\left.\mathrm{ha}^{-1}\right)$ was obtained from November -10 sowing that similar to December $\left(0.99 \mathrm{t} \mathrm{ha} \mathrm{a}^{-1}\right)$ and January $\left(0.90 \mathrm{t} \mathrm{ha}^{-1}\right)$ sowing and the lowest straw yield $\left(0.38 \mathrm{t} \mathrm{ha}^{-1}\right)$ from March -10 sowing. The highest harvest index (47.06\%) was obtained from December-10 sowing that similar to November (46.58\%) and January (45.12\%) sowing and the lowest (40.63\%) from March -10 sowing (Table 2).

Table 2. Effect of cultivar and sowing date on yield and other parameters of quinoa

\begin{tabular}{|c|c|c|c|c|c|}
\hline Treatments & $\begin{array}{l}\text { Inflorescence } \\
\text { length }(\mathrm{cm})\end{array}$ & $\begin{array}{l}\text { Wt. of } 1000 \\
\text { seeds }(\mathrm{g})\end{array}$ & $\begin{array}{c}\text { Grain yield } \\
\left(\mathrm{t} \mathrm{ha}^{-1}\right)\end{array}$ & $\begin{array}{c}\text { Straw yield } \\
\left(\mathrm{t} \mathrm{ha}^{-1}\right)\end{array}$ & $\begin{array}{c}\text { Harvest } \\
\text { index (\%) }\end{array}$ \\
\hline \multicolumn{6}{|c|}{ Effect of cultivar } \\
\hline Titicaca & 22.01 & 2.05 & $0.77 \mathrm{a}$ & $0.89 \mathrm{a}$ & 46.39 \\
\hline Vikinga & 25.18 & 2.03 & $0.61 \mathrm{~b}$ & $0.76 \mathrm{~b}$ & 44.53 \\
\hline $\operatorname{LSD}_{(0.05)}$ & NS & NS & 0.089 & 0.104 & NS \\
\hline CV $(\%)$ & 9.23 & 12.89 & 8.52 & 4.28 & 6.76 \\
\hline \multicolumn{6}{|c|}{ Effect of sowing date } \\
\hline November - 10 & $29.62 \mathrm{a}$ & $2.56 \mathrm{a}$ & $1.09 \mathrm{a}$ & $1.25 \mathrm{a}$ & $46.58 \mathrm{a}$ \\
\hline December - 10 & $28.33 \mathrm{ab}$ & $2.47 \mathrm{a}$ & $0.88 \mathrm{bc}$ & $0.99 a b$ & $47.06 \mathrm{a}$ \\
\hline January - 10 & $25.27 \mathrm{~b}$ & $2.25 \mathrm{~b}$ & $0.74 \mathrm{c}$ & $0.90 \mathrm{~b}$ & $45.12 \mathrm{ab}$ \\
\hline February - 10 & $20.86 c$ & $1.75 \mathrm{c}$ & $0.48 \mathrm{~d}$ & $0.62 \mathrm{bc}$ & $43.64 \mathrm{~b}$ \\
\hline March - 10 & $13.86 \mathrm{~d}$ & $1.17 \mathrm{~d}$ & $0.26 e$ & $0.38 \mathrm{c}$ & $40.63 c$ \\
\hline $\operatorname{LSD}_{(0.05)}$ & 3.094 & 0.145 & 0.187 & 0.372 & 2.268 \\
\hline CV $(\%)$ & 10.71 & 5.81 & 10.26 & 4.20 & 7.86 \\
\hline
\end{tabular}

Figures in a column with common letter(s) do not differ significantly at $5 \%$ probability level.

\section{Interaction effect of cultivar and sowing date}

Interaction between cultivar and sowing date showed significant differences on plant height at 15 and 30 DAS and at harvest (Table 3). At 15 DAS, the highest plant height $(50.78 \mathrm{~cm})$ was observed in $\mathrm{C}_{1} \mathrm{~S}_{4}$ (Titicaca with February -10 sowing) which was at par with $\mathrm{C}_{1} \mathrm{~S}_{3}, \mathrm{C}_{2} \mathrm{~S}_{3}$ and $\mathrm{C}_{2} \mathrm{~S}_{4}$. The lowest plant height $\left(20.89 \mathrm{~cm}\right.$ ) was observed in $\mathrm{C}_{2} \mathrm{~S}_{1}$ (Vikinga with November -10 sowing) which was statistically similar with $\mathrm{C}_{2} \mathrm{~S}_{2}, \mathrm{C}_{2} \mathrm{~S}_{5}, \mathrm{C}_{1} \mathrm{~S}_{1}$ and $\mathrm{C}_{1} \mathrm{~S}_{5}$. At 30 DAS, the highest plant height $(65.36 \mathrm{~cm})$ was observed in $\mathrm{C}_{1} \mathrm{~S}_{1}$ (Titicaca with November -10 sowing) that statistically similar with $\mathrm{C}_{1} \mathrm{~S}_{2}, \mathrm{C}_{1} \mathrm{~S}_{4}, \mathrm{C}_{1} \mathrm{~S}_{3}$ and $\mathrm{C}_{2} \mathrm{~S}_{3}$.

The lowest plant height $\left(33.99 \mathrm{~cm}\right.$ ) was observed in $\mathrm{C}_{2} \mathrm{~S}_{5}$ (Vikinga with March -10 sowing) that similar with $\mathrm{C}_{1} \mathrm{~S}_{5}, \mathrm{C}_{2} \mathrm{~S}_{2}$ and $\mathrm{C}_{2} \mathrm{~S}_{1}$. At harvest, the highest plant height $(72.83 \mathrm{~cm})$ was found in $\mathrm{C}_{1} \mathrm{~S}_{1}$ (Titicaca with November -10 sowing) which was statistically similar with $\mathrm{C}_{1} \mathrm{~S}_{2}, \mathrm{C}_{1} \mathrm{~S}_{4}$ and $\mathrm{C}_{1} \mathrm{~S}_{3}$. The lowest plant height $\left(37.09 \mathrm{~cm}\right.$ ) was observed in $\mathrm{C}_{2} \mathrm{~S}_{5}$ (Vikinga with March -10 sowing) that similar to $\mathrm{C}_{1} \mathrm{~S}_{5}$. At $15 \mathrm{DAS}$, the highest branch number plant ${ }^{-1}$ (23.93) was observed in $\mathrm{C}_{1} \mathrm{~S}_{3}$ (Titicaca with January -10 sowing) that similar to $\mathrm{C}_{2} \mathrm{~S}_{3}$. The lowest branch number plant ${ }^{-1}$ (5.60) was observed in $\mathrm{C}_{2} \mathrm{~S}_{1}$ (Vikinga with November -10 sowing) that similar to $\mathrm{C}_{1} \mathrm{~S}_{1}$. 
Table 3. Interaction effect of cultivar and sowing date on plant height and branch number plant ${ }^{-1}$ of quinoa

\begin{tabular}{lcccccc}
\hline Interactions & \multicolumn{3}{c}{ Plant height (cm) at } & \multicolumn{3}{c}{ Branches plant $^{-1}$ (no.) at } \\
\cline { 2 - 7 } & $15 \mathrm{DAS}$ & $30 \mathrm{DAS}$ & Harvest & $\mathbf{1 5} \mathrm{DAS}$ & 30 DAS & Harvest \\
\hline $\mathrm{C}_{1} \mathrm{~S}_{1}$ & $24.34 \mathrm{def}$ & $65.36 \mathrm{a}$ & $72.83 \mathrm{a}$ & $5.40 \mathrm{e}$ & $10.13 \mathrm{c}$ & $25.20 \mathrm{a}$ \\
$\mathrm{C}_{1} \mathrm{~S}_{2}$ & $35.61 \mathrm{~b}-\mathrm{e}$ & $65.23 \mathrm{a}$ & $71.57 \mathrm{a}$ & $9.33 \mathrm{c}$ & $13.08 \mathrm{c}$ & $21.21 \mathrm{bc}$ \\
$\mathrm{C}_{1} \mathrm{~S}_{3}$ & $48.50 \mathrm{ab}$ & $57.40 \mathrm{ab}$ & $62.80 \mathrm{ab}$ & $23.93 \mathrm{a}$ & $25.88 \mathrm{a}$ & $22.20 \mathrm{abc}$ \\
$\mathrm{C}_{1} \mathrm{~S}_{4}$ & $50.78 \mathrm{a}$ & $57.55 \mathrm{ab}$ & $63.15 \mathrm{ab}$ & $12.66 \mathrm{c}$ & $14.67 \mathrm{bc}$ & $8.46 \mathrm{de}$ \\
$\mathrm{C}_{1} \mathrm{~S}_{5}$ & $28.20 \mathrm{c}-\mathrm{f}$ & $42.20 \mathrm{~cd}$ & $48.40 \mathrm{~cd}$ & $9.73 \mathrm{~cd}$ & $11.50 \mathrm{c}$ & $5.86 \mathrm{e}$ \\
$\mathrm{C}_{2} \mathrm{~S}_{1}$ & $20.89 \mathrm{f}$ & $43.78 \mathrm{~cd}$ & $52.10 \mathrm{bc}$ & $5.60 \mathrm{e}$ & $10.13 \mathrm{c}$ & $20.40 \mathrm{c}$ \\
$\mathrm{C}_{2} \mathrm{~S}_{2}$ & $23.42 \mathrm{ef}$ & $43.74 \mathrm{~cd}$ & $53.50 \mathrm{bc}$ & $9.06 \mathrm{~d}$ & $13.56 \mathrm{c}$ & $24.47 \mathrm{ab}$ \\
$\mathrm{C}_{2} \mathrm{~S}_{3}$ & $39.96 \mathrm{abc}$ & $53.85 \mathrm{abc}$ & $58.12 \mathrm{bc}$ & $23.26 \mathrm{a}$ & $25.78 \mathrm{a}$ & $24.70 \mathrm{ab}$ \\
$\mathrm{C}_{2} \mathrm{~S}_{4}$ & $38.36 \mathrm{a}-\mathrm{d}$ & $46.46 \mathrm{bc}$ & $52.31 \mathrm{bc}$ & $16.63 \mathrm{~b}$ & $18.90 \mathrm{~b}$ & $11.83 \mathrm{~d}$ \\
$\mathrm{C}_{2} \mathrm{~S}_{5}$ & $24.13 \mathrm{def}$ & $33.99 \mathrm{~d}$ & $37.09 \mathrm{~d}$ & $11.54 \mathrm{~cd}$ & $12.14 \mathrm{c}$ & $7.15 \mathrm{e}$ \\
\hline $\mathrm{LSD}_{(0.05)}$ & 14.284 & 12.373 & 11.713 & 3.397 & 4.985 & 3.824 \\
$\mathrm{CV}_{(\%)}$ & 24.69 & 14.03 & 11.83 & 15.44 & 18.49 & 12.88 \\
\hline
\end{tabular}

Figures in a column with common letter(s) do not differ significantly at $5 \%$ probability level.

$\mathrm{C}_{1}=$ Titicaca, $\mathrm{C}_{2}=$ Vikinga, $\mathrm{S}_{1}=$ November $-10, \mathrm{~S}_{2}=$ December $-10, \mathrm{~S}_{3}=$ January $-10, \mathrm{~S}_{4}=$ February -

10 and $S_{5}=$ March -10 sowing

At 30 DAS, the highest number of branches plant ${ }^{-1}$ (25.88) was observed in $C_{1} S_{3}$ (Titicaca with January -10 sowing) that also similar to $\mathrm{C}_{2} \mathrm{~S}_{3}$ (Vikinga with January -10 sowing). The lowest number of branches plant ${ }^{-1}$ (10.13) was observed in $C_{1} S_{1}$ (Titicaca with November -10 sowing) that identical to $\mathrm{C}_{2} \mathrm{~S}_{1}$ (Vikinga with November -10 sowing) and similar with $\mathrm{C}_{1} \mathrm{~S}_{5}, \mathrm{C}_{2} \mathrm{~S}_{5}, \mathrm{C}_{1} \mathrm{~S}_{2}$, $\mathrm{C}_{2} \mathrm{~S}_{2}$ and $\mathrm{C}_{1} \mathrm{~S}_{4}$. At harvest, the highest branch number plant ${ }^{-1}(25.20)$ was found in $\mathrm{C}_{1} \mathrm{~S}_{1}$ (Titicaca with November -10 sowing) that similar to $\mathrm{C}_{2} \mathrm{~S}_{3}, \mathrm{C}_{2} \mathrm{~S}_{2}$ and $\mathrm{C}_{1} \mathrm{~S}_{3}$. The lowest number of branches plant ${ }^{-1}$ (5.86) was observed in $\mathrm{C}_{1} \mathrm{~S}_{5}$ (Titicaca with March -10 sowing) that similar to $\mathrm{C}_{2} \mathrm{~S}_{5}$.

Interaction between cultivar and sowing dates showed significant differences on inflorescence length plant ${ }^{-1}$ at harvest (Table 4). The tallest inflorescence $(31.46 \mathrm{~cm})$ was found in $\mathrm{C}_{2} \mathrm{~S}_{2}$ (Vikinga with December -10 sowing) which was statistically similar with $\mathrm{C}_{2} \mathrm{~S}_{1}, \mathrm{C}_{1} \mathrm{~S}_{1}$ and $\mathrm{C}_{2} \mathrm{~S}_{3}$. The shortest inflorescence $\left(13.37 \mathrm{~cm}\right.$ ) was observed in $\mathrm{C}_{1} \mathrm{~S}_{5}$ (Titicaca with March -10 sowing) that similar to $\mathrm{C}_{2} \mathrm{~S}_{5}$. The highest 1000 -seed weight $(2.58 \mathrm{~g})$ was found in $\mathrm{C}_{1} \mathrm{~S}_{1}$ (Titicaca with November -10 sowing) which was similar to $\mathrm{C}_{2} \mathrm{~S}_{1}, \mathrm{C}_{2} \mathrm{~S}_{2}$ and $\mathrm{C}_{1} \mathrm{~S}_{2}$. The lowest 1000-seed weight $(1.10 \mathrm{~g})$ was observed in $\mathrm{C}_{2} \mathrm{~S}_{5}$ (Vikinga with March -10 sowing) that similar to $\mathrm{C}_{1} \mathrm{~S}_{5}$ (Titicaca with March -10 sowing). The highest seed yield $\left(1.16 \mathrm{t} \mathrm{ha}^{-1}\right)$ was found in $\mathrm{C}_{1} \mathrm{~S}_{1}$ (Titicaca with November -10 sowing) that similar to $C_{2} S_{1}\left(1.01 t^{t} a^{-1}\right)$ and $C_{1} S_{2}\left(0.96 t^{-1} a^{-1}\right)$ and the lowest seed yield $\left(0.21 \mathrm{t} \mathrm{ha}^{-1}\right)$ in $\mathrm{C}_{2} \mathrm{~S}_{5}$ (Vikinga with March -10 sowing) that similar to $\mathrm{C}_{1} \mathrm{~S}_{5}$ and $\mathrm{C}_{2} \mathrm{~S}_{4}$. The highest straw yield $\left(1.33 \mathrm{t} \mathrm{ha}^{-1}\right.$ ) was found in $\mathrm{C}_{1} \mathrm{~S}_{1}$ (Titicaca with November -10 sowing) which was statistically similar to $C_{2} S_{1}$ and $C_{1} S_{2}$ and the lowest straw yield $(0.33 \mathrm{t}$ ha $^{-1}$ ) was observed in $\mathrm{C}_{2} \mathrm{~S}_{5}$ (Vikinga with March -10 sowing) that similar to $\mathrm{C}_{1} \mathrm{~S}_{5}, \mathrm{C}_{2} \mathrm{~S}_{4}$ and $\mathrm{C}_{1} \mathrm{~S}_{4}$. The highest harvest index (47.02\%) was found in $\mathrm{C}_{2} \mathrm{~S}_{2}$ (Vikinga with December -10 sowing) that similar to all interactions except $\mathrm{C}_{2} \mathrm{~S}_{5}$ and $\mathrm{C}_{2} \mathrm{~S}_{4}$ those were statistically similar. 
Table 4. Interaction effect of cultivar and sowing date on yield and other parameters of quinoa

\begin{tabular}{lccccc}
\hline Interactions & $\begin{array}{c}\text { Inflorescence } \\
\text { length }(\mathbf{c m})\end{array}$ & $\begin{array}{c}\text { Wt. of } \mathbf{1 0 0 0} \\
\text { seeds (g) }\end{array}$ & $\begin{array}{c}\text { Grain yield } \\
\left(\mathbf{t ~ h a}^{-1}\right)\end{array}$ & $\begin{array}{c}\text { Straw yield } \\
\left(\mathbf{t ~ h a}^{-1}\right)\end{array}$ & $\begin{array}{c}\text { Harvest } \\
\text { index (\%) }\end{array}$ \\
\hline $\mathrm{C}_{1} \mathrm{~S}_{1}$ & $28.50 \mathrm{~b}$ & $2.58 \mathrm{a}$ & $1.16 \mathrm{a}$ & $1.33 \mathrm{a}$ & $46.59 \mathrm{a}$ \\
$\mathrm{C}_{1} \mathrm{~S}_{2}$ & $25.20 \mathrm{~b}-\mathrm{d}$ & $2.47 \mathrm{ab}$ & $0.96 \mathrm{ab}$ & $1.09 \mathrm{abc}$ & $46.83 \mathrm{a}$ \\
$\mathrm{C}_{1} \mathrm{~S}_{3}$ & $23.13 \mathrm{c}-\mathrm{e}$ & $2.20 \mathrm{c}$ & $0.86 \mathrm{bc}$ & $0.97 \mathrm{bc}$ & $46.99 \mathrm{a}$ \\
$\mathrm{C}_{1} \mathrm{~S}_{4}$ & $19.77 \mathrm{e}$ & $1.75 \mathrm{~d}$ & $0.54 \mathrm{def}$ & $0.63 \mathrm{de}$ & $46.15 \mathrm{a}$ \\
$\mathrm{C}_{1} \mathrm{~S}_{5}$ & $13.37 \mathrm{f}$ & $1.24 \mathrm{e}$ & $0.31 \mathrm{fg}$ & $0.43 \mathrm{e}$ & $41.89 \mathrm{ab}$ \\
$\mathrm{C}_{2} \mathrm{~S}_{1}$ & $30.73 \mathrm{a}$ & $2.53 \mathrm{a}$ & $1.01 \mathrm{ab}$ & $1.16 \mathrm{ab}$ & $46.54 \mathrm{a}$ \\
$\mathrm{C}_{2} \mathrm{~S}_{2}$ & $31.46 \mathrm{a}$ & $2.46 \mathrm{ab}$ & $0.79 \mathrm{bcd}$ & $0.89 \mathrm{bcd}$ & $47.02 \mathrm{a}$ \\
$\mathrm{C}_{2} \mathrm{~S}_{3}$ & $27.40 \mathrm{a}-\mathrm{c}$ & $2.30 \mathrm{~b}$ & $0.62 \mathrm{cde}$ & $0.83 \mathrm{~cd}$ & $42.76 \mathrm{ab}$ \\
$\mathrm{C}_{2} \mathrm{~S}_{4}$ & $21.96 \mathrm{de}$ & $1.74 \mathrm{~d}$ & $0.41 \mathrm{efg}$ & $0.61 \mathrm{de}$ & $40.20 \mathrm{~b}$ \\
$\mathrm{C}_{2} \mathrm{~S}_{5}$ & $14.34 \mathrm{f}$ & $1.10 \mathrm{e}$ & $0.21 \mathrm{~g}$ & $0.33 \mathrm{e}$ & $38.89 \mathrm{~b}$ \\
\hline $\mathrm{LSD}_{(0.05)}$ & 4.374 & 0.205 & 0.249 & 0.326 & 5.875 \\
$\mathrm{CV}(\%)$ & 10.71 & 5.81 & 10.26 & 4.20 & 7.86 \\
\hline
\end{tabular}

$\mathrm{C}_{1}=$ Titicaca, $\mathrm{C}_{2}=$ Vikinga, $\mathrm{S}_{1}=$ November $-10, \mathrm{~S}_{2}=$ December $-10, \mathrm{~S}_{3}=$ January -10 ,

$\mathrm{S}_{4}=$ February -10 and $\mathrm{S}_{5}=$ March -10 sowing

\section{Conclusion}

Quinoa can be successfully cultivate in Bangladesh during Rabi season. The cultivar Titicaca performed better compared to that of Vikinga. Among the five sowing dates, sowing at November-10 gave the highest grain yield where cultivar Titicaca sown in November could be the best combination.

\section{Acknowledgements}

The author acknowledged the financial authority of Sher-e-Bangla Agricultural University, Dhaka - 1207 for support to startup the research on a new crop Quinoa under the umbrella of SAURES (Sher-e-Bangla Agricultural University Research System) Research grant. The support from Dr. Md. Sekender Ali, Pro Vice-Chancellor of Sher-e-Bangla Agricultural University also gratefully acknowledged for providing seeds of two quinoa cultivars collected from DAE.

\section{References}

Bazile, D., C. Pulvento, A. Verniau, M.S. Al-Nusairi, D. Ba, J. Breidy, L. Hassan, M.I. Mohammed, O. Mambetov, M. Otambekova, N.A. Sepahvand, A. Shams, D. Souici, K. Miri and S. Padulosi. 2016. Worldwide evaluations of quinoa: Preliminary results from post international year of quinoa, FAO projects in 9 countries, Front Plant Sci. 7: 850.

Bazile, D., H.D. Bertero and C. Nieto. 2015. State of the Art Report on Quinoa Around the World in 2013; Roma: FAO \& CIRAD: 589.

Bazile, D. 2014. State of the art report on quinoa around the world in 2013. In: Bazile, D. (ed) Food and Agriculture Organizations of the United Nations (FAO), Santiago.

Bhargava, A., S. Shukla and D. Ohri. 2006. Chenopodium quinoa-an Indian perspective. Ind. Crop. Prod. 23: 73-87.

FAOSTAT. 2020. Quinoa production in 2018. UN Food and Agriculture Organization, Corporate Statistical Database. 
Fernando, S.V., S.V. Edmar, G.B. Marcel and S. Lucas. 2012. Development and productivity of quinoa sown on different dates during off-season. Revista Ciencia Agron. 43(3): 510-515.

Gomez, K.A. and A.A. Gomez. 1984. Statistical Procedure for Agricultural Research (2nded.). Int. Rice Res. Inst., A Willey Int. Sci. Pub. pp.28-192.

Jahan, K. and M. Hossain. 1998. Nature and extent of malnutrition in Bangladesh: Bangladesh national nutrition survey 1995-96. Dhaka: Institute of Nutrition and Food Sciences, University of Dhaka; p.33.

Koyro, H.W. and S. Eisa. 2007. Effect of salinity on composition viability and germination of seeds of Chenopodium quinoa Willd. Plant Soil. 302(1): 79-90.

Louafi, S., D. Bazile and J.L. Noyer. 2013. Conserving and cultivating agricultural genetic diversity: going beyond established cleavages. In: Cultivating biodiversity to transform agriculture. Versailles: Ed. Quae, pp.185-222.

Pulvento, C., M. Riccardi, A. Lavini, R. D’Andria, G. Jafelice and E. Marconi. 2010. Field trial evaluation of two Chenopodium quinoa genotypes grown under rainfed conditions in a typical Mediterranean environment in South Italy. J. Agron. Crop Sci. 196: 407-411.

Ramesh, K., K.B. Suneetha Devi, K.A. Gopinath and M. Uma Devi. 2017. Growth, yield and economics of quinoa as influenced by different dates of sowing and varied crop geometry. Int. J. Pure Appl. Biosci. 5(6): 849-854.

Risi, J.C. and W.G. Nicholas. 1991. Effects of sowing date and sowing rate on plant development and grain yield of quinoa (Chenopodium quinoa) in a temperate environment. The J. Agril. Sci. 117(03): 325-332.

Sajjad, A., H. Munir, Ehsanullah, S.A. Anjum, M. Tanveer and A. Rehman. 2014. Growth and development of quinoa (Chenopodium quinoa willd.) at different sowing dates. Agri. Res. 52(4): 535-546.

Troiani, R.M., T.M. Sanchez, N.B. Reinaudi and L.A. de Ferramola. 2004. Optimal sowing dates of three species of grain -bearing amaranth in the semi-arid Argentine pampa. Spanish Agri. Res. 2(3): 385-391.

World Bank. 2005. Maintaining Momentum to 2015: An impact evaluation of interventions to improve maternal and child health and nutrition in Bangladesh. Washington, The World Bank. 